\title{
Comparative Effect of Aqueous Datura (Datura metal) Extract and A Gentamicin on The quick Healing of The Wound in Thigh Region in Laboratory Rats
}

\author{
R.M.Almussawi* W. M. Aldughman** I. M.H. Alrashid** S. K. Majeed*** \\ * Coll. of Sci/ Unive. of Basrah \\ ** Vet. Med. Coll./ Unive. of Basrah \\ *** Coll.of Vet. Med. / Unive. of Basrah
}

\begin{abstract}
The present study is achieved for observing and evidence the effect of Datura Aqueous Extraction (DAE) on the success the quick repair the cutaneous wound in thigh region in lab rats which are infected with Saphyllococcus aureus. The study is achieved in 28 mature rats ,those same age and weight $(250 \pm 25 \mathrm{~g}), 8$ month age and live at similar condition.The animals are divided into three groups, $1^{\text {st }}$ and $2^{\text {nd }}$ was contain 10 rat $(5 \mathrm{mal}+5 \mathrm{femal})$ in treated groups while control group was contain 4 rat which subdivided into (4male+4female) and in all groups were made surgical wound (superficial) in thigh region.The $1^{\text {st }}$ (Datura) and $2^{\text {nd }}$ (Gentamicin) groups were infected by staph. aureus with $10^{-8}$ titration of germs. After $48 \mathrm{hr}$ the both groups are treated the $1^{\text {st }}$ by DAE $10 \mathrm{mg} / \mathrm{kg}$ b.w. and $2^{\text {nd }}$ by Gentamicin $5 \% \mathrm{w} / \mathrm{w}$ as well as sham-control subgroup is leave.The control group was subdivided into two subgroup, the $1^{\text {st }}$ subgroup (standard subgroup) was leaved stay sterile wound without infection (superficial disinfection), recovery without treatment (self cure), the other were infected with staph. aureus and leaved without treatment.The experiment is evidencing the quick healing of wound that is treated with (DAE), compare with the wound that treated with Gentamicin. There are no destructive change in microscopic histopathology due to less toxic effect of datura, as well as blood parameter is good evidence in datura group. Statically analysis was achieved by SPSS v. 16.0, there are significant results of datura compare with other groups, no significant results of gentamicine group and standard control subgroup while significant with sham-control subgroup $\mathrm{P}<0.05$.
\end{abstract}

Key word : Datura, wound healing, gentamicine

\section{Introduction}

Datura metal (saolanacae) is a popular or widely medicinal uses include of dried leaves of plant as anti-cholenergic agent $^{1,2,3}$. As well as it use as an anti-ulcer, pain relief, and nervous system stimulator, hyoscine ${ }^{4,5}$.Phytochemical detected in plant alkaloid atropine and scopolamine and other chemical composition ${ }^{6}$.This plant was tested as anti-microbial by Weckbach and Langlois ${ }^{7}$, they use Staphylococcus aurous betray-dish with plant extraction disc, the diameter of inhibition zone were measured by using ruler and size of inhibition were by KirbyBaur method ${ }^{8}$. wound infection have been thought of as infection in surgical wound occurring between the skin and deep soft tissue. There are three factors effect on wound healing: 1-bacteria or infectious agents,2-host defense mechanisms, 3- surgical sites 9 . Antimicrobial or antibiotic should be taken by inconsideration the side effect and cellular toxicity, Datura metal extraction either plant or seed are toxic in human or animal have been reported ${ }^{10}$. therefore, the use of $D$. metal extraction have many risk and the using of plant as skin ointment is suitable ${ }^{11}$. The effect of $D$. metal on the liver and kidney function were estimated by Gidado et al. , they showed increase total billiorubin, urea, creatinine, liver enzymes and plasma ions ( $\mathrm{Cl}^{-}, \mathrm{Na}^{+}, \mathrm{K}^{+}$), when they used the plant with food intake $(200 \mathrm{mg} / \mathrm{kg} . \mathrm{bw})$ daily ${ }^{10}$. Other effect of $D$. metal in the body was reported in lung, heart, and nervous system by Knight and Walter, Francis, Beasly , Artoud and Langdon ${ }^{12,13,14,15}$. Other researches were study the analgesic effect of D. metal such as Wannang et al. 
because the plant have pre-medication anesthesia such as atropine and hyoscine ${ }^{16}$.Gentamicin is bactericidal aminoglycocide antibiotic with wide clinical uses but distributing toxicity, nephrotoxicity, and ototoxicity are most common adverse reaction. Gentamicin is a specify to Gram+ bacteria ${ }^{23}$. attempts to further the incidence of postoperative wound sepsis have included gentamicin irrigation prosthesis implantation ${ }^{24-}$. Numbers of risk factors associated with treatment by gentamicin such as volume depletion, metabolic acidosis, hypokalemia, $\mathrm{Ca}^{++}$deficiency, free radical generation, and ascorbic acid deficiency $^{23,25}$. there are many attempts to reduce the gentamicin toxicity by addition some agent or drugs such as sodium bicarbonate, high calcium diet, vitamin Bcomplex, and vitamin $\mathrm{C}^{23,25,27}$. The aim of present study to knowledge of herbal extract (Datura) to treatment wound infection and its side effects.

\section{Material and Methods}

28 adult rats(male + female 50:50), they a live in similar condition (feeding, temperature, and water). Aqueous Datura extraction $(10 \%)^{12}$, gentamicine ointment (5\%)w/w. [RBCs, WBCs, HB, and PCV] apparatuses.Anesthesia was used the mixture of ketamine+xylazine $(100 \mathrm{mg}+10 \mathrm{mg})$ with $\mathrm{dose}(30 \mathrm{mg} / \mathrm{kgbw})^{19}$, as well as surgical instruments.Prepare the animals to shaving the thigh region at lateral view by hair removal cream, after 5 minutes the area wash by water and alcohol to each animals, after than made incision $2 \mathrm{~cm}$ in thigh region by surgical blade $^{17}$.Animals are massacred by cervical dislocation method and the blood is drowned by DETA test tubes for blood examinations and knowledge the effect of therapy on blood parameters. The rats were divided into three groups, Datura group, Gentamicin group, and control group, the last was subdivided into two subgroups: standard-control and sham. covered with cotton saturated by $70 \%$ ethyl

\begin{tabular}{|c|c|c|c|}
\hline \multicolumn{4}{|c|}{ total animals28 } \\
\hline $\begin{array}{c}\text { Datura group } \\
(10)\end{array}$ & \begin{tabular}{c} 
Gentamicin group \\
\cline { 3 - 4 }
\end{tabular} & $\begin{array}{c}\text { Standard-control subgroup } \\
(4)\end{array}$ & $\begin{array}{c}\text { Sham- control } \\
\text { subgroup (4) }\end{array}$ \\
\hline
\end{tabular}

All rats were exposed infection by Staphylococcus aurous $10^{-8}$ except standard control subgroup, after $48 \mathrm{hr}$ when inflammation signs appears on the wound, they were treated by Datura extraction at Datura group, and Gentamicin at Gentamicin group, while the sham-control subgroup was leaved without treatment.Blood examination were estimated by classical method, HB was estimated by Salhi' method, RBCs and

\section{Results}

The clinical signs of surgical wounds incision are normal in two days post surgery, but after 3 days the sings of inflammation were began except standard subgroup control were leaved without infection. The severity of inflammation after treatment were vary from group to other, in Datura group were showed faster
WBCs were estimated by counter champers slid under light microscope and PCV was estimated by microcentrifuge $^{20}$.Skin wound pictures were toke by digital (12 migapixal) china origin, Canon.Were prepared from skin wound healing by toke specimens from skin contain wound edges and maintain in formalin solution $10 \%$ and prepared slides, stain with eosin and heamatoxylin staining technique $^{18}$.

healing, while Gentamicin group were less than the first, but both group were faster than two subgroup control fig(1). The effect of Datura, Gentamicin on the internal organs were showed histopathologically in the fig(2) compare with two subgroups control. The blood parameters were summarized in this table (1) 
Fig (2) wounds gross pictures

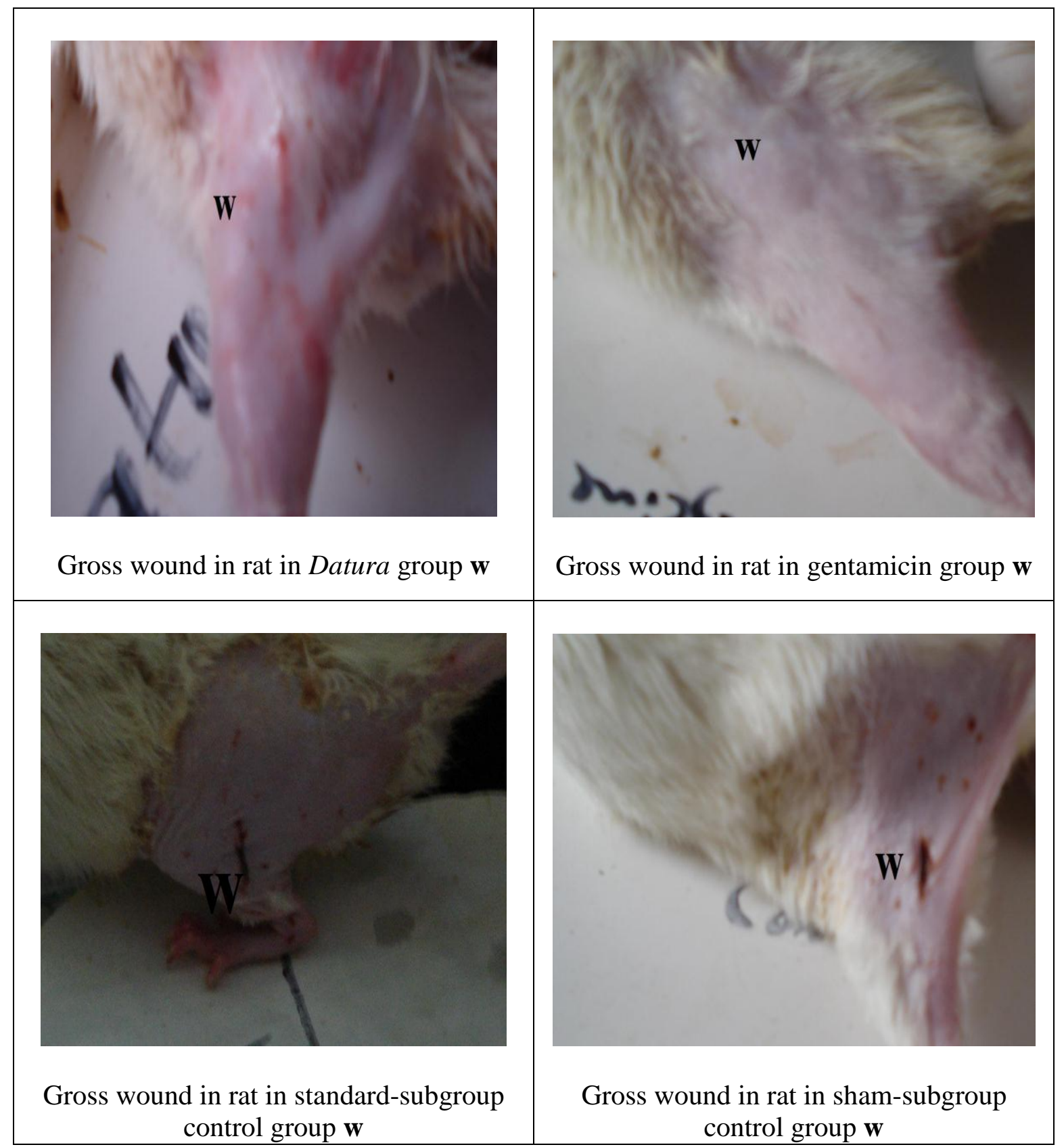


Fig (3) histopathological section in skin of rat groups

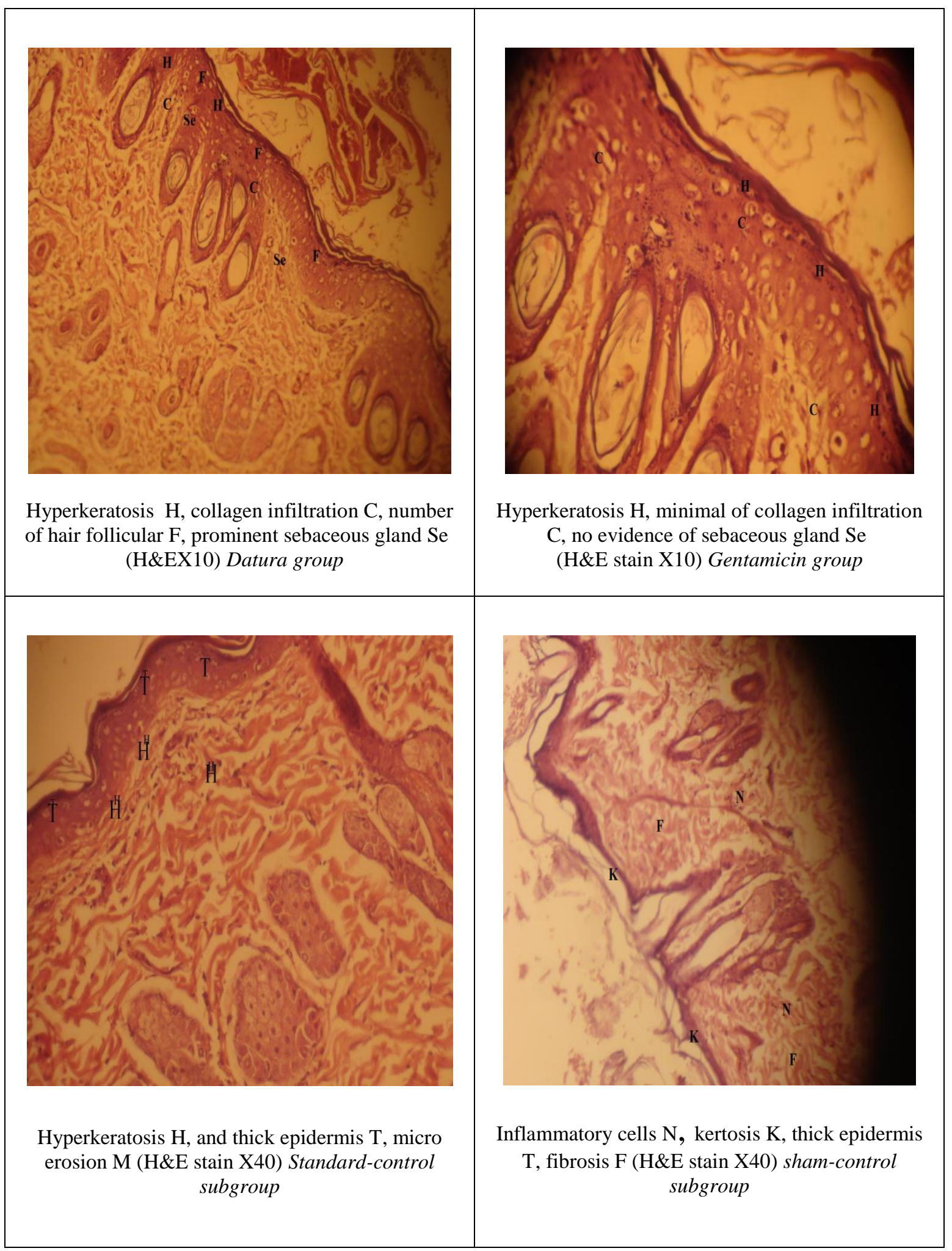


Fig (4) histopathological section in kidney of rat groups

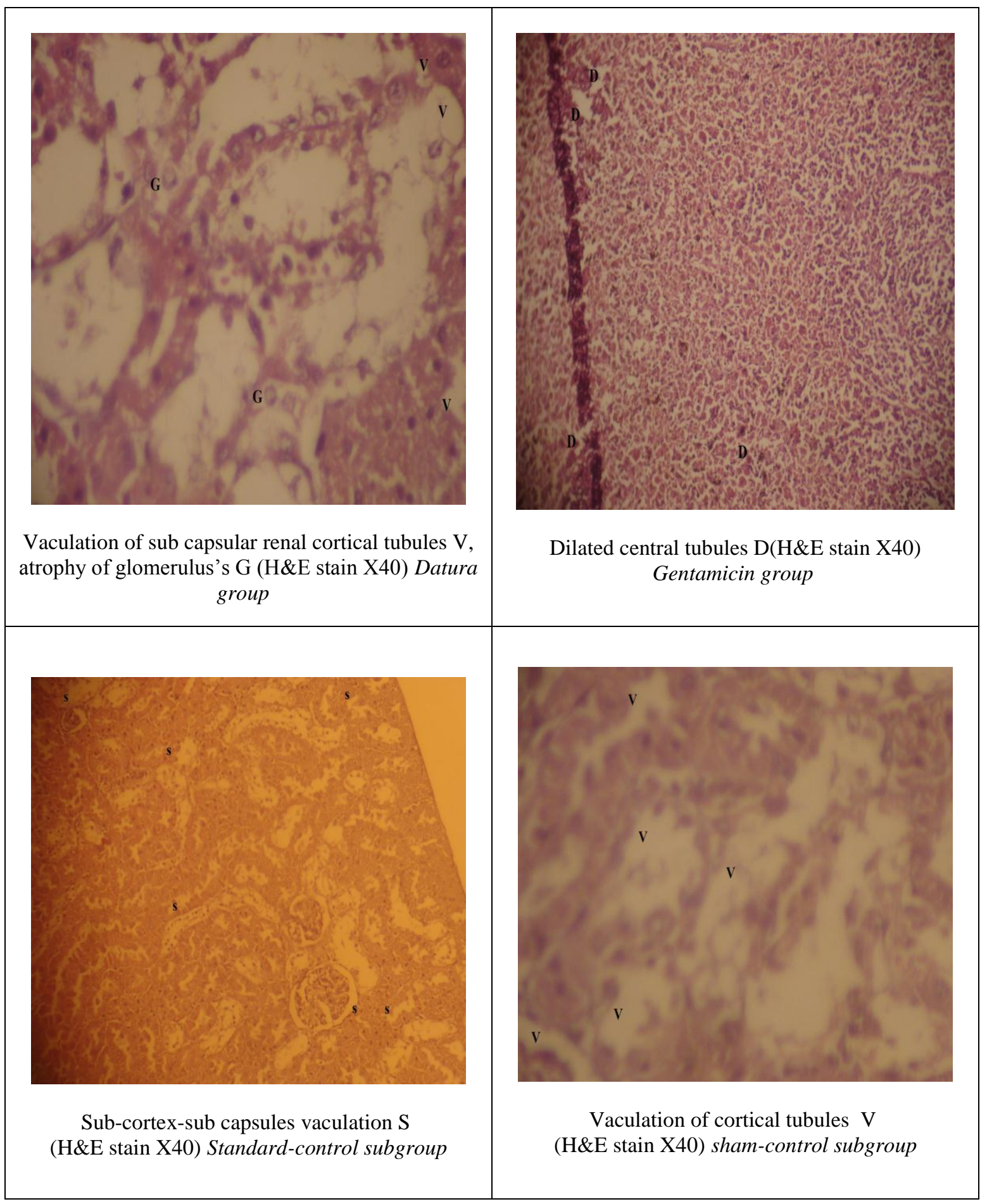


Fig (5) histopathological section in liver of rat groups

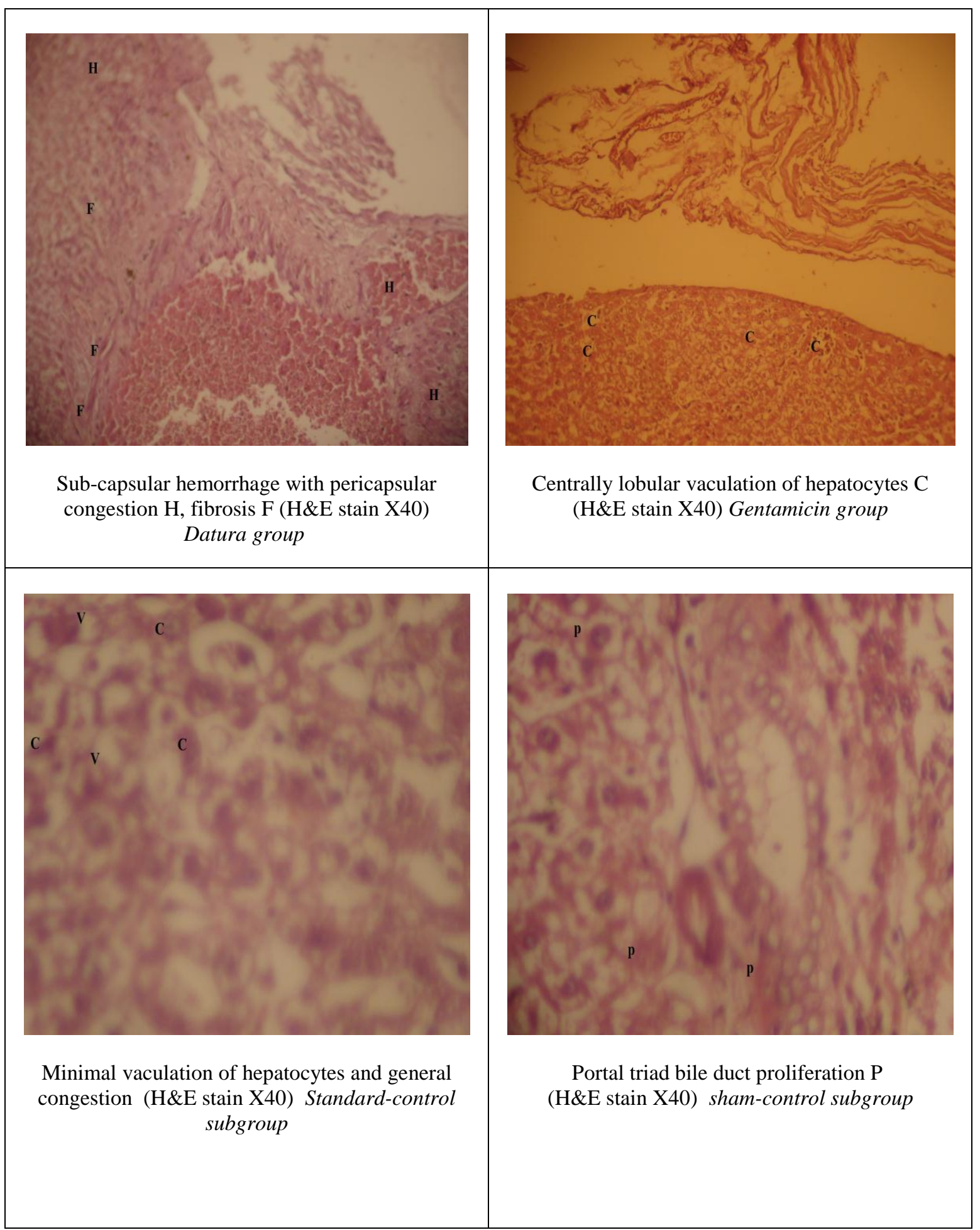


Fig (6) histopathological section in spleen of rat groups

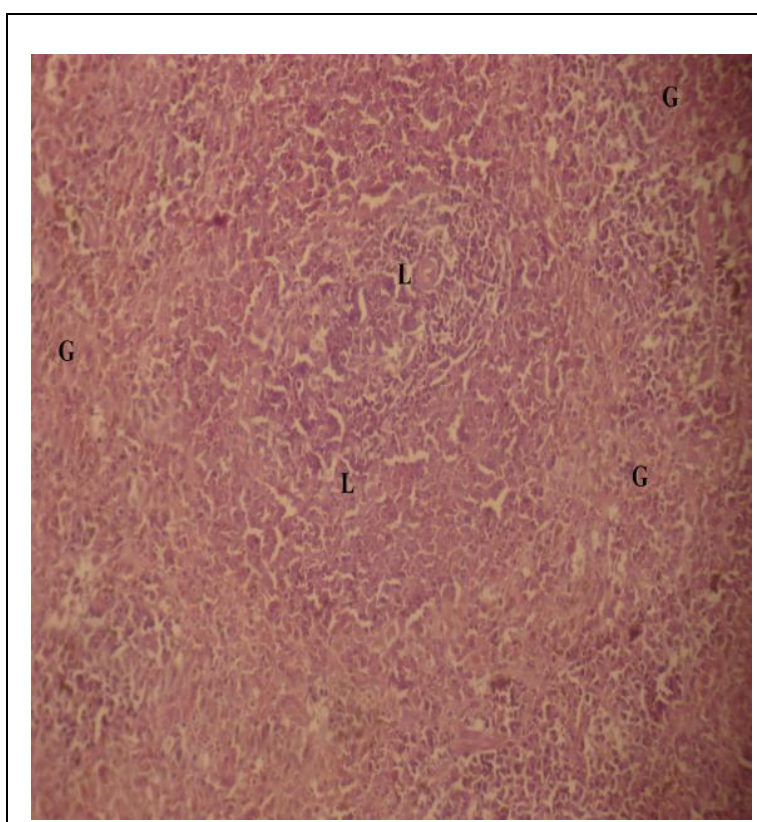

Lymphoid hyperplasia L, germinal central formation G (H\&E stain X40) Datura group

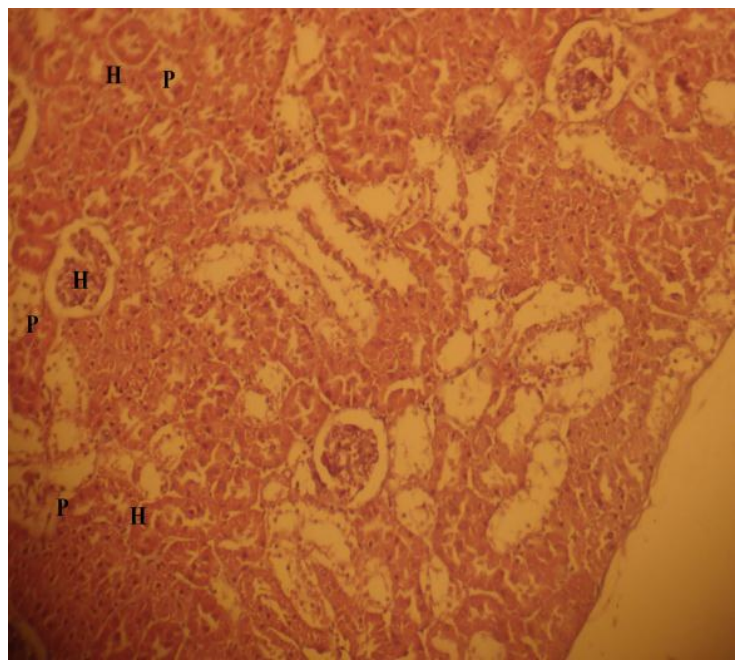

White pulp lymphoid hypertrophy $\mathrm{H}$ and hyperplasia $\mathrm{p}$ (H\&E stain X40) Standard-control subgroup

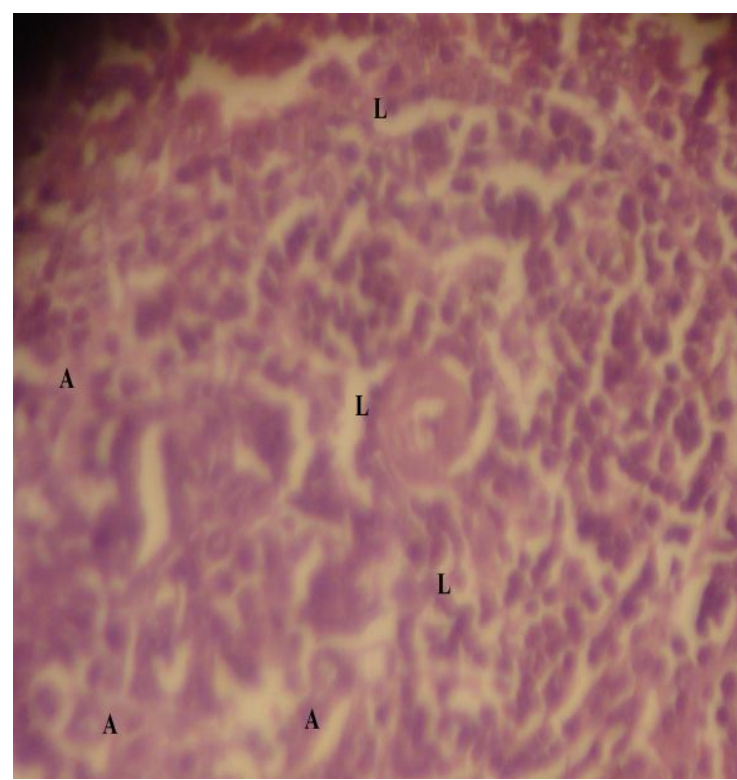

Atrophy of white pulp A, lymphoid hyperplasia L (H\&E stain X40) Gentamicin group

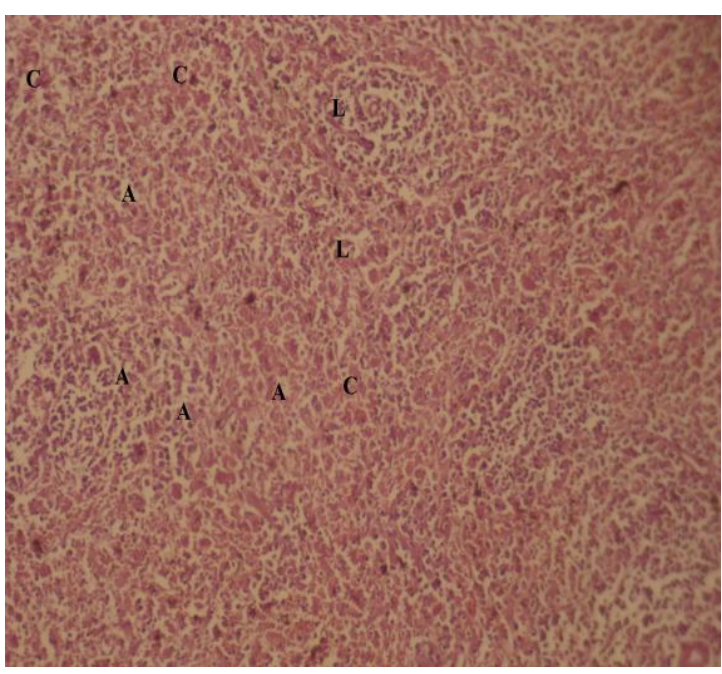

White pulp atrophy A, lymphoid hyperplasia L, general congestion $\mathrm{C}$ (H\&E stain X40) shamcontrol subgroup 
Table (1) blood parameters in rats groups

\begin{tabular}{|c|c|c|c|c|c|c|c|c|}
\hline \multirow{2}{*}{$\begin{array}{c}\text { parameters } \rightarrow \\
\text { groups } \downarrow\end{array}$} & \multicolumn{2}{|c|}{ RBCs* $10^{5} / \mathrm{dl}$} & \multicolumn{2}{|c|}{ WBCs $* 10^{3} / \mathrm{dl}$} & \multicolumn{2}{|c|}{ PCV } & \multicolumn{2}{|c|}{$\mathrm{HB}$ g/dl } \\
\hline & $\mathrm{M}^{*}$ & $\mathrm{~F}$ & $\mathrm{M}$ & $\mathrm{F}$ & $\mathrm{M}$ & $\mathrm{F}$ & $\mathrm{M}$ & $\mathrm{F}$ \\
\hline Datura $^{\S}$ & $80.6^{* *} \pm 9.6^{* * *}$ & $75 \pm 40$ & $5.5 \pm 5.3$ & $5.6 \pm 4.3$ & $51 \pm 1.7$ & $50 \pm 6.08$ & $12.5 \pm 0.8$ & $12 \pm 0.35$ \\
\hline gentamicine $^{\text {II }}$ & $76.1 \pm 16.2$ & $70 \pm 31.04$ & $8.8 \pm 6.08$ & $8 \pm 5.56$ & $49 \pm 8.77$ & $45 \pm 2.64$ & $14.8 \pm 0.6$ & $14 \pm 2.64$ \\
\hline $\begin{array}{l}\text { standard subgroup } \\
\text { control }\end{array}$ & $70.2 \pm 0.24$ & $70 \pm 7.5$ & $10 \pm 10.2$ & $9 \pm 5.4$ & $43 \pm 1.44$ & $40 \pm 2.32$ & $7.3 \pm 0.9$ & $7.5 \pm 2.22$ \\
\hline $\begin{array}{c}\text { sham-subgroup } \\
\text { control }\end{array}$ & $53.8 \pm 11.3$ & $50 \pm 22.5$ & $11 \pm 1.08$ & $11 \pm 7.5$ & $37 \pm 5.45$ & $35 \pm 2.67$ & $11.5 \pm 1.3$ & $11 \pm 0.98$ \\
\hline
\end{tabular}

** mean

$* * * \mathrm{SD}$ (standard deviation)

$\S \mathrm{P}<0.05$ significant results with other groups

II $\mathrm{P}<0.05$ no significant results with standard subgroup control while significant results sham-subgroup control

Table(2) comparative among treated groups and control groups

\begin{tabular}{|c|c|c|c|c|}
\hline \multicolumn{5}{|c|}{ Comparative among groups macroscopically } \\
\hline organs & Datura & Gentamicine & standard-control & Sham-control \\
\hline Skin(superficially) & Show line of wound healing & $\begin{array}{c}\text { Show normal skin without line of } \\
\text { wound healing }\end{array}$ & $\begin{array}{l}\text { Open-wound and clearly } \\
\text { show edges of wound }\end{array}$ & $\begin{array}{c}\text { Show scar tissue elevated on } \\
\text { wound healing line }\end{array}$ \\
\hline \multicolumn{5}{|c|}{ Comparative among groups microscopically } \\
\hline Skin tissue & $\begin{array}{l}\text { Hyperkeratosis , collagen infiltration, } \\
\text { number of hair follicular, prominent } \\
\text { sebaceous gland }\end{array}$ & $\begin{array}{l}\text { Hyperkeratosis, minimal of collagen } \\
\text { infiltration, no evidence of } \\
\text { sebaceous gland }\end{array}$ & $\begin{array}{l}\text { Hyperkeratosis, and thick } \\
\text { epidermis , micro erosion }\end{array}$ & $\begin{array}{l}\text { Inflammatory cells, kertosis, } \\
\text { thick epidermis , fibrosis }\end{array}$ \\
\hline kidney & $\begin{array}{l}\text { Vaculation of sub capsular renal } \\
\text { cortical tubules, atrophy of } \\
\text { glomerulus's }\end{array}$ & Dilated central tubules & $\begin{array}{l}\text { Sub-cortex-sub capsules } \\
\text { vaculation }\end{array}$ & Vaculation of cortical tubules \\
\hline liver & $\begin{array}{l}\text { Sub-capsular hemorrhage with } \\
\text { pericapsular congestion, fibrosis }\end{array}$ & $\begin{array}{c}\text { Centrally lobular vaculation of } \\
\text { hepatocytes }\end{array}$ & $\begin{array}{c}\text { Minimal vaculation of } \\
\text { hepatocytes and general } \\
\text { congestion }\end{array}$ & $\begin{array}{l}\text { Portal triad bile duct } \\
\text { proliferation }\end{array}$ \\
\hline spleen & $\begin{array}{l}\text { Lymphoid hyperplasia, germinal central } \\
\text { formation }\end{array}$ & $\begin{array}{c}\text { Atrophy of white pulp , lymphoid } \\
\text { hyperplasia }\end{array}$ & $\begin{array}{c}\text { White pulp lymphoid } \\
\text { hypertrophy and hyperplasia }\end{array}$ & $\begin{array}{l}\text { White pulp atrophy, } \\
\text { lymphoid hyperplasia, } \\
\text { general congestion }\end{array}$ \\
\hline
\end{tabular}




\section{Discussion}

Datura metal herb is most common herbal medicine as alkaloid pharmacology, and there are agrees and disagrees with other researchers in the internal medicine and microbiology field, but in surgery there are no researches discuss yet. $D$. metal have anti microbial effect against several bacteria such as Staph. aurous, E. coli, K. pneumonia and other bacteria. This properties to regard to tannin, glycosides compounds, and alkaloid compounds, these agree with other such as Wannang ${ }^{10}$ et al., Gidado ${ }^{11}$ et al., and other $^{12,15}$. Toxological effect of D. metal don't showing clearly and significant changes in organs and blood parameters, the reason may regard to the few amount which used in experiment or the rout of administration (skin ointment 10\%) or both, while other researchers were used in oral administration, they show changes in blood organs, therefore this herb should be don't use orally alone in spite of the professional of herbal medicine regard $D$. metal is safe herbal medicine compare with other species ${ }^{15}$.The factors which effect on wound healing are antimicrobial activity of D. metal extraction, atropine effect on blood vessels, irritation effect of tannic acid which accelerate the wound healing, and formation of scar tissues ${ }^{21}$, as well as the analgesic effect of $D$. metal on wound healing also help the animals to don't crushing the edges of wound ${ }^{22}$. Gentamicin activity against bacteria (wound infection) and also the role of gentamicin in wound healing were agreed with other studies such as Souza et al. ${ }^{27}$, Sorger et al. $^{28}$ and Fallahzadeh et al. ${ }^{26}$, while the side effect of gentamicin in our study were showed more severity compare with $D$. metal, this result also agreed with other searchers such as Lee et $\mathrm{al}^{25}$, Lee et al. ${ }^{24}$, Bello et al. ${ }^{23}$; they showing significant changes pathologically and physiologically while our study used skin infiltration as skin ointment also show pathological changes, therefore they used other agent to advantaged the gentamicin effect such as vitamin B-complex, vitamine $\mathrm{C}$ and soduium bicarbonate ${ }^{23,24,25}$. The genera of animals no effect in wound healing significantly, and all animals in resent study were similar age, while in other studies were showed different response to wound healing in young and older rats such as Gidado et $a l^{11}$, Beasley et $a l^{14}$. The effect of D. metal on the normal physiology of rats no significant in present study because of few dose was absorbed in body, while Bello et $a \mathrm{l}^{23}$ and Lee et al ${ }^{25}$ were showed toxic nephrosis.

\section{References}

1-John D (1984) One hundred useful drugs of Kanitribes of division, kerala, Inter J Crude Drug Res. Vol. 22, pp : 17-39.

2-Sezik E, Zor M, Yesilada E. (1992) Traditional medicine in TurkeyII : flok medicine in Kastamonu. Inter J pharmaco. Vol.30, pp 3951.

3-De Foe V, Senator F. (1993) Medicinal plants and phytotherapy in Amel fitan cost, Salerno province compania,, southern of Italy. J Ethropharmacol. Vol. 39, pp:3335.

4-Guharov S R, Barajas M (1991) Intense stimulant effect : atropine intoxication from the ingesion and smoking of Jimson weed (Datura stramonium). Vet Toxicol. Vol. 33, pp:588-589.

5-Manadhav N P(1995) Inventory of some herbal drugs of Myagai district . Nepal Econ Bot. Vol. 49, pp:371379.

6-Giral F, Hidalogo C C (1983) Presence of alkaloids in Mexican plant. Int J Crude Drug Res. Vol. 21, pp;113.

7-Weckbach J, Langlois S (1964) Poisonous plant of the United States and Canada. Pentice-Hall, Inc. Englewood Cliffs N J. pp: 331-400.

8-Kirby-Baur A W (1966) Antibiotic susceptibility testing by 
standardized single disk method. Am J Clinpath. Vol. 45, 493-496.

9-Meakins J, Masterson B (2005) Prevention of post operative infection. In basic surgical operative consideration. $\mathrm{pp}: 13$ 33.

10-Gidado A, Zainab A, Hadiza M, Serah D, Anas H, Milala M (2007) Toxicity studies of ethanol extraction of leaves of Datura stramonium in rats. African $\mathbf{J}$ Biotechn. Vol. 6(7), pp: 10121015.

11-Mac Dougal D, Maureen E, Hamilton G (1996) Indian plants poisonous to livestock and pets, Durdue University

(http://vet.purdue.edu/dept/add1/t oxic/conver1.htm) .

12-Knight A P, Walter R G (2003) Plants Affecting the digestive system: cited in A guide to Plant poisonous of animals in north America by Knight and Walter. International Veterinary Information Service (www.ivis.org), Ithaca, New York, USA.

13-Francis J K (2003) Toxicity of plant extracts to three storage beetles Coleopatera) J Applied Entem. Vol. 3(2), pp: 202-208.

14-Beasely V (1999) Toxicant that affect the autonomic nervous system :cited in Veterinary Toxicology by Beasley. International Veterinary Information Service (www.ivis.org) Ithaca, new York, USA.

15-Artaud C R, Langdon K R (1977) Datura sp. Weed, ornamental, drug, poison; with Bizarre Medical History. Nematolologyb J No 25.

16-Wannang N N, Ndukwe K, Nnabuife A ( 2009) Evaluation of analgesic properties of Datura metal seeds aqueous extraction. J Med Plan Res. Vol. 3(4), pp: 192-195.

17-Harari J (1996) Small Animals Surgery. $3^{\text {rd }}$ ed. William and
Wilkins , Waverly Co.

Washington. USA. pp: 27-37.

18-Bancroft JD, Stevens A, Pears AG (1975) Histochemical techniques, $2^{\text {nd }}$. Butter-worth Co. ltd. Great Britain. pp33-35.

19-Lee L (2006) Veterinary Anesthesiology . born veterinary technical hospital, college of veterinary medicine, Oklahoma State University. $4^{\text {th }}$ ed Mac Donald Co. pp :32-34.

20-Coles, E.H. (1986). Veterinary clinical pathology, Fourth Edition, W.B. Saunders.

21-WHO (2004) Essential Drug and Medicine Policy. Edm www.who.int.

22-Mutschler E, Harbmut D (1995) Pathophysiology of pain : Analgesics, drug action, Basic principle and therapeutic aspect. Med Pharm Sci Publishers Stuttgart. pp:149-153.

23-Bello SO, Chika A (2009) Dose Dependent Amelioration of Gentamicin- Induced Nephrotoxicity in Adult Swiss Albino Rats by Vitamin Bcomplex. Topical J Pharm Res, vol. 8(2), pp:111-116.

24-Lee KH, Nag A, Tan TB, Mossianac K (2008) Systemic Absorption of Gentamicin Irrigation in Joint Replacement Surgery. Malaysian Orthoped J, vol. 2(2),pp:11-16.

25-Lee HY, Choi KH, Bank N (1988) Protective Effect of Urinary Alkalinization on Gentamicin Nephrotoxicity in Rats. Yonsei Med J, vol. 29(3), pp:225-232.

26-Fallahzadeh MH, Noorfshan A, Tanideh N, Badeli HR, Bazargani A (2004) Effect of Betamethasone and Gentamicin on Renal Scarring Induced by Mannose-sensitive E. coli pylonephritis in Rats. Imm J Med Surg, vol. 29(3),pp:130-133.

27-Souza VB, Oliveira RF, Lucena HF, Ferrira AA, Gurra GC, Freitas ML, Queiros KC, Junior 
RF(2009) Gentamicin Induced

Renal Morphopathology in

Wister Rats. Int J Morphol, vol. 27(1), pp:59-63.

28-Sorger JI, Bhandari M, Holtom PD

(1999) Once Daily High Dose versus divided low dose gentamicin for open fractures. Clin Orthoped J, vol. 366, pp:179-204.

\section{تأثير مقارن لمستخلص الاتورا المائي (Datura metal) والجنتامايسين على الجي سرعة التأم الجروح الجلدية في منطقة الفخذ للجرذان المختبرية}

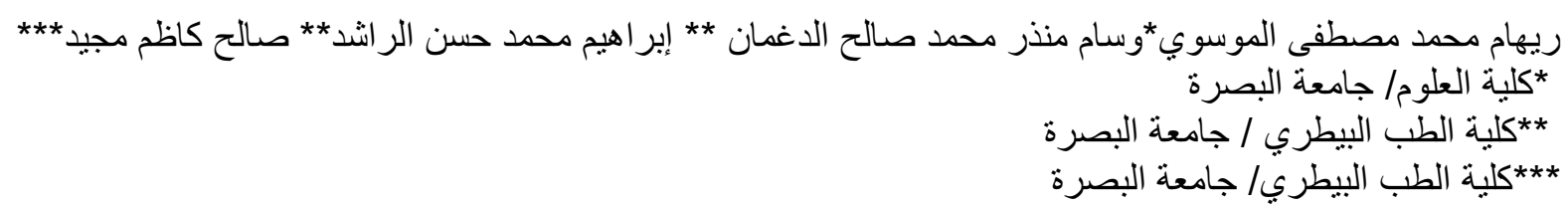

\section{الخلاصة}

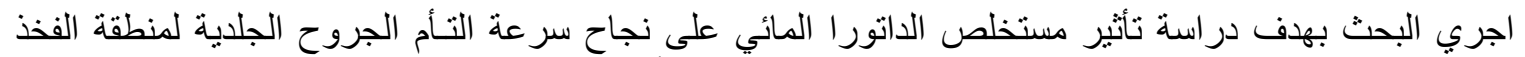

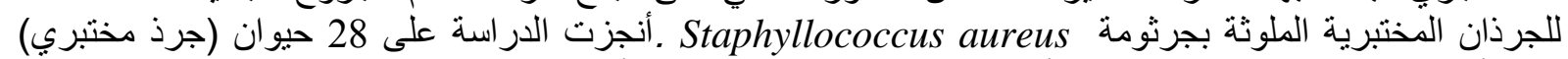

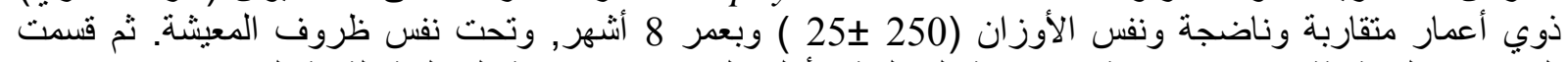

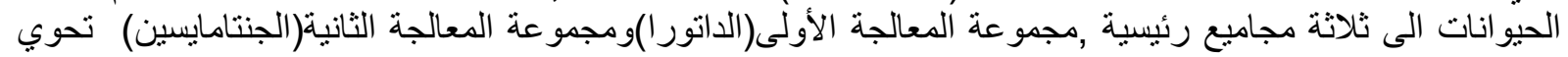

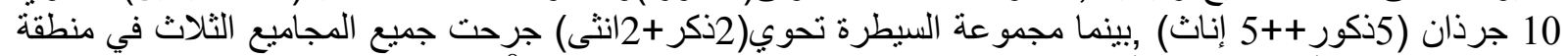

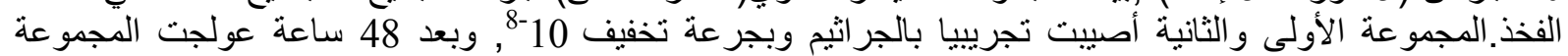

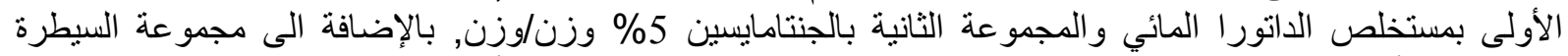

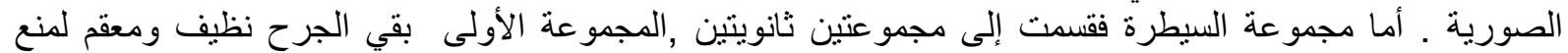

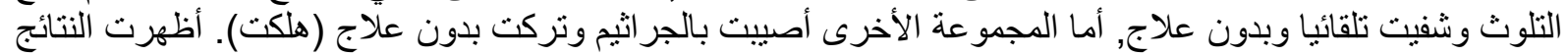

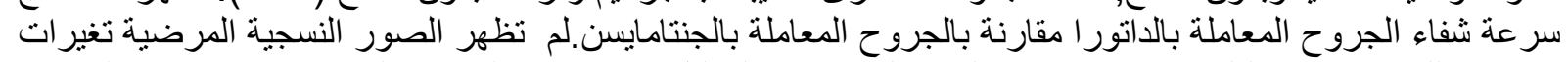

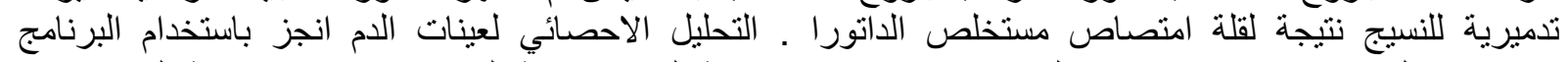

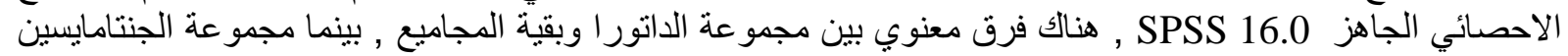

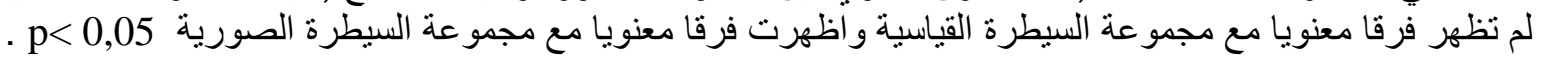

